A changing climate of skepticism? The factors shaping climate change coverage in the US press

Hannah Schmid-Petri*

Silke Adam*

Ivo Schmucki*

Thomas Häussler*

University of Bern

Institute of Communication and Media Studies

Fabrikstrasse 8

3012 Bern, Switzerland

Corresponding author: Hannah Schmid-Petri; email: Hannah.Schmid-Petri@ikmb.unibe.ch,

Important Note: This is the final version of the manuscript as published in Public Understanding of Science:

Schmid-Petri, H., Adam, S., Schmucki, I. \& Häussler, T. (2015). A changing climate of skepticism? The factors shaping climate change coverage in the US press. Public Understanding of Science. Online first, DOI: 10.1177/0963662515612276

Funding:

This publication was created in the context of the Research Unit "Political Communication in the Online World" (1381), subproject 7, which is funded by the DFG, German Research Foundation. The subproject is also funded by the Swiss National Science Foundation (SNF, 100017E135915). 


\section{A changing climate of skepticism? The factors shaping climate change coverage in the US press}

\section{Introduction}

Handling the impacts of climate change is one of humanity's biggest challenges. Over the past 40 years, the scientific community has come to the consensus that human activities are at least partly responsible for climate change and that immediate action has to be taken to mitigate global warming (Anderegg et al., 2010; IPCC, 2014; Doran \& Zimmermann, 2009; Oreskes, 2004). But, although the issue is present on the international political agenda, to date there is no binding international agreement to curb climate change that includes all major emitters worldwide.

Especially in the US skepticism towards climate change or its consequences has a long tradition (Dunlap \& McCright, 2008; 2010) and is present in many parts of society. Many members of the political administration, mainly Republicans, publicly doubt the human contribution to climate change and argue that regulations to cut down greenhouse gas emissions would have severe economic consequences (Fisher, Waggle \& Leifeld, 2013; Selin \& vanDeever, 2010). Public opinion polls repeatedly show that climate change is not among people's top concerns (Gallup, 2014a; Scruggs \& Benegal, 2012) and 40\% of the US American population believes that natural causes explain the rise in the earth's temperature (Gallup, 2014b), though the percentage of those who say they feel informed about the topic has risen. In the mass media coverage the percentage of skeptical voices and arguments are relatively high compared to other countries (Boykoff \& Boykoff, 2004; Dispensa \& Brulle 2003; Grundmann, 2007; Grundmann \& Scott, 2014; Painter \& Ashe, 2012; Antilla, 2005). This leads to the (false) impression that the evidence supporting global warming is highly uncertain and helped rendering skeptical views legitimate.

Given that tackling climate change is one of the most pressing issues of our time, this paper continues and replicates the work of previous studies (especially Boykoff \& Boykoff, 2004 and Painter \& Ashe, 2012) and examines the US print media's more recent coverage of climate change. This allows us to develop a long-term perspective from which we then can reconstruct possible shifts and changes in the climate change debate. Because as scientific evidence has strengthened, and as the political atmosphere has changed at least slightly with the attempts of the democratic Obama administration to put climate protection on the political agenda, we might observe a debate that has changed as well. Therefore our first research question is: To what degree and in what form is climate change skepticism still a characteristic of US print media coverage?

Our second question refers to the factors that might explain when and why climate advocates and skeptics enter US mass media debates. We investigate two theoretical strands that have been advanced to explain media coverage of climate change: First, we examine whether the distribution of voices of advocacy and skepticism in the coverage can be explained by the effect of journalistic neutrality (known as "balance as bias") - the approach taken by Boykoff and Boykoff (2004; see also Boykoff \& Rajan, 2007; Boykoff \& Boykoff, 2007). Next, we investigate whether possible differences within the coverage might be the result of political parallelism and partisan media, as shown by Painter and Ashe (2012) as well as Elsasser and Dunlap (2013). 
With our study we contribute to the question of how the scientific issue of climate change is translated into mass media coverage in a three-fold manner. First, we use more recent empirical data (June 2012 until May 2013) to detect the relevance of different forms of climate skepticism in the US print coverage; second our study can show the evolution of the climate debate in the US as we replicate indicators of former studies; third, we contribute to a better understanding which media-relevant variables make climate skepticism salient in public debate. Taking stock, tracking the evolution as well as digging for explicative factors of media coverage of climate change skepticism is crucial as this coverage has the potential to impact public opinion (e.g. Zaller, 1992) as well as political action (e.g. Baumgartner \& Jones, 1993).

To answer our research questions, we proceed in five steps: First, we present the US context of climate change politics. Second, we derive hypotheses about possible forms of climate change skepticism and the factors that might contribute to making climate change skepticism a salient characteristic of US print coverage. Third, we introduce the logic of our quantitative content analysis. Thereby we show how we replicate the indicators for climate change skepticism used in former studies. In a fourth section, we present our empirical data and finally conclude with a larger discussion of the role of the media in climate change debate in the US.

\section{The debate about climate change in the US}

The United States display a development of climate change politics that puts them in stark contrast to most other advanced industrial societies and has created opportunities for a strong climate skeptical movement to take hold. While the US was considered for some time an "environmental pioneer" (Dryzek et al., 2003, p. 174) and the 1960s and 1970s still saw the implementation of progressive environmental policies, the 1980s mark a turning point with the advent of an antienvironmentalism that tied in seamlessly into the vestiges of anti-communism (Jacques, Dunlap \& Freeman, 2008). A larger conservative movement consisting of think tanks, conservative foundations, part of the media, public intellectuals and politicians (supported by the fossil fuel industry) perceived the increasing importance of environmental issues on the political agenda and the signing of international treaties such as the United Nations Framework Convention on Climate Change as a threat to national autonomy and the economy (Dunlap \& McCright, 2008). In the wake of the "Republican Revolution" of Congress during the Clinton administration in 1994 that gave conservative politicians a majority in both houses, climate change became one of the core issues on which Republicans attacked Democrats, scientists and the environmental movement (McCright \& Dunlap, 2011). The withdrawal of the US from the Kyoto Protocol in 2001 and the increasing polarization of Congress meant that climate skepticism became an identifier of conservative convictions (Brownstein, 2010). Following the financial and economic crises of 2008, the weak agreement reached by the Copenhagen Climate Change Conference in 2009, several mistakes that surfaced in IPCC data and leaked emails between scientists ("climategate", Leiserowitz et al., 2013), political opportunities for national climate change policies have become considerably smaller (Gupta, 2010). And despite recent efforts by the Obama administration to revive climate change politically by introducing several bills (Aldy \& Pizer, 2009), opposition to national legislation remains strong and the most effective policy implementations have been made on the level of federal states and cities that cooperate on the issue (Lutsey \& Sperling, 2008). Throughout this development the media have played a crucial role in at least two ways. First, 
conservative media - particularly television (Feldman et al., 2011) - have made climate change one of their causes on which they have mobilised anti-environmentalist public sentiment. Second, irrespective of their political position the media have generally amplified climate skeptical voices (i.e. Boykoff \& Boykoff 2004; Painter \& Ashe, 2012; Grundmanm \& Scott, 2014). Getting a deeper understanding of the media's coverage of climate change is therefore paramount to understanding the structure and dynamic of climate skepticism.

\section{Climate change skepticism in US print media}

\section{The various forms of climate change skepticism}

Climate change skepticism has different facets which the countermovement uses strategically to frame the discussion about climate change and to avoid binding decisions towards reducing $\mathrm{CO}_{2}$ emissions. The literature distinguishes three types of skepticism (Rahmstorf 2004; Hobson \& Niemeyer, 2012; Painter, 2011; Painter \& Gavin, 2015): two of them refer to fundamental forms of skepticism and one articulates a more subtle version of it.

Fundamental forms of skepticism directly contradict the scientific consensus and thus imply the denial of scientific evidence (Washington \& Cook, 2011; Diethelm, \& McKee, 2009). "Fundamental skeptics" either deny the trend of global warming as such - labelled trend skeptics by Rahmstorf (2004) or deep skeptics by Hobson and Niemeyer (2012) - or they question the anthropogenic attribution respectively deny that there is sufficient evidence to determine the causes of climate change - labelled attribution skeptics by Rahmstorf (2004) or causal skeptics by Hobson and Niemeyer (2012).

More subtle forms of skepticism in turn neither question the trend nor the anthropogenic causes of climate change but shift the focus to two counter-claims (Dunlap \& McCright, 2010): First, if global warming were to occur, it would be largely beneficial, and second, proposed policies designed to limit global warming would be very harmful to the free market, bring disadvantages to the national economy and threaten individual freedom and thus no actions are needed or should be at best non-binding - a position labeled "impact" skepticism by Rahmstorf (2004) and Hobson and Niemeyer (2012) (similarly Capstick and Pidgeon (2014) name this type of skepticism "response skepticism").

There is ample evidence that fundamental forms of climate change skepticism have long existed in US print media coverage. In a study of four major US newspapers (New York Times, Los Angeles Times, Washington Post and Wall Street Journal), Boykoff and Boykoff (2004) show that a fundamental form of skepticism, the denial of anthropogenic causes for climate change, appears in $59 \%$ of the analyzed articles. In line with this, Painter and Ashe's (2012) analysis of the Climategate affair (November 2009 - February 2010) and the publication of the IPCC report (February - April 2007 ) reveals a substantial amount of trend and attribution skeptics ( $75 \%$ of the skeptics quoted in the articles), while Elsasser and Dunlap (2013) identify the skeptical argument "it's not happening" (trend skeptics) as most commonly used by conservative columnists in op-eds.

There is also empirical evidence for impact skepticism. In the same study quoted above, Boykoff and Boykoff (2004) report that $11 \%$ of the articles call for cautious or voluntary actions - which is 
one aspect of impact skepticism. Further, in their comparative study Painter and Ashe (2012) show that impact skeptics are mostly found in UK and US print media $-25 \%$ of the quoted skeptics are impact skeptics - compared to other countries (for the UK see also Painter \& Gavin, 2015). Elsasser and Dunlap (2013) found that conservative columnists argue that the impacts of global warming would not be harmful and that policy regulations would be negative (see also Boykoff, 2012).

However, more recent studies report less fundamental forms of skepticism. In a follow-up study on US and UK data from 2003 to 2006, Boykoff (2007a) found that after 2003, no articles were identified that question the existence of an anthropogenic contribution to climate change (see also Russill \& Nyssa, 2009). Similarly, Hickman (2013, p. 1) states that the form of skepticism has changed over time in the sense that "rather than claiming that climate science is a hoax, a fraud or fundamentally flawed, they [skeptics] now say the proposed climate policies will have little, if any, impact on the planet's temperature gauge and are therefore a waste of time and money." These findings are in line with the results found by Hiles and Hinnant (2014) who interviewed environmental journalists. They state that it is no longer possible to question the manmade contribution to global warming but what is debatable is how much and what to do to combat climate change (p. 439).

Based on these findings our first hypothesis tests in how far climate skepticism in the media has changed from fundamental to more subtle forms which, however, still follow the goal of avoiding binding policy regulations to reduce $\mathrm{CO}_{2}$ emissions. We therefore claim:

\section{H1: Impact skepticism is more salient in US print media coverage today than fundamental forms of skepticism.}

\section{Explaining climate change skepticism in US print media}

The literature presents two basic explanations why and how skepticism makes it into the media, measured on two different levels: First, on the level of the single article the journalistic norm of neutrality leads to what is known as "balance as bias," whereas on the level of whole newspapers political parallelism results in differences between outlets. Thus far, no study has attempted to examine which of the factors better explains how skeptical views enter print media coverage.

Neutrality as a core journalistic norm in the US translates into everyday reporting as a balance norm: journalists always try to give both sides in a conflict the possibility to speak up (Entman, 1989; p. 30). As a result, climate change skeptics and advocates are both given a chance to raise their voices. Viewed against the backdrop of the scientific consensus on the man-made contribution to climate change (IPCC, 2014), this has serious consequences: climate change skeptics are over-represented in the coverage. The resulting "balance as bias" (Boykoff \& Boykoff, 2004 , p. 126) is further exacerbated by the fact that journalists are often not trained to analyze scientific studies or competing knowledge (Stocking, 1999; Stocking \& Holstein, 2009; Dunwoody \& Peters, 1992; Boykoff, 2007b).

There is also some empirical evidence for the US that the media's logic of balance makes climate skeptics enter the debate. Boykoff and Boykoff (2004) found that in 53\% of articles the 
argumentation is balanced, referring to anthropogenic as well as natural causes for climate change. Concerning actions to combat climate change, $78 \%$ of articles evenly discuss mandatory and voluntary actions. However, in more recent years, articles that balance fundamental skepticism and advocacy have dropped from 37\% in 2003 to 3\% in 2006 (Boykoff, 2007a; see also Nisbet, 2011). Also Xie (2015) shows a decline of balanced articles (starting 2005) in the New York Times, USA Today and the Washington Post to a nearly non-skeptical coverage in 2008 (see also Hiles \& Hinnant, 2014).

This result indicates that the logic of balancing no longer seems to structure fundamental questions of climate change (which resonates with hypothesis 1 ). However, as previous results do not show a homogenous picture concerning the occurrence of balance as bias - especially with the focus on impact skepticism, we formulate an exploratory research question:

RQ1: Is the US print media coverage about climate change still balanced, i.e. features arguments from climate change skeptics and advocates within each article?

A second strand of research that addresses why climate change skeptics are taken up by US media refers to the concept of political parallelism (Hallin \& Mancini, 2004). Political parallelism suggests that media outlets have distinct political orientations that match those found within the political realm. Hallin and Mancini (2004) attribute high levels of political parallelism to countries of the polarized pluralist type (e.g. the Mediterranean countries), whereas they judge the US system - the ideal type of a liberal system - as being characterized by low levels of parallelism combined with a neutral, balance-oriented press. However, since 2004 Hallin and Mancini's seminal work was published, partisan media have reemerged in the US (e.g. Iyengar \& Hahn, 2009; Levendusky, 2013). This trend is especially pronounced in TV, with FOX news representing the more conservative side and $\mathrm{CNN}$ the more liberal side of partisan media. Partisan media are expected to privilege their political ideology by giving voice to specific issues and their respective advocates. Climate change is one of the most polarizing issues in the US, with possibilities for political land grabbing (Fisher, Leifeld, \& Iwaki, 2013; Hoffman, 2011). It clearly divides climate change advocates (typically politically liberal) and a strong anti-environmental countermovement driven by conservatives, tightly tied to American nationalism (Brulle, forthcoming; Fisher, Waggle \& Leifeld, 2013; McRight \& Dunlap, 2003, 2011; Nisbet, 2009; Nisbet \& Mooney, 2007). If political parallelism tends to insert climate change skepticism into the media debate, we would expect a clear cut divide between conservative and liberal media:

H2: Conservative media publish more skeptical articles compared to liberal media - in their reporting as well as commentating.

Support for this hypothesis is found in the UK. Here, a newspaper's ideology plays a crucial role in the presentation of climate change skepticism: it is the conservative Times that is more inclined to question scientific evidence compared to the liberal Guardian or the Independent (Carvalho, 2007; Carvalho \& Burgess, 2005), as well as the conservative Daily Mail that departs most strongly from scientific mainstream views (Boykoff \& Mansfield 2008). Furthermore uncontested skeptical opinion is more present in right-leaning than in left leaning newspapers (Painter \& Gavin, 2015, p. 14). For the US, the results are less clear cut. Painter and Ashe (2012) found hardly any difference between the reporting of the liberal New York Times (25\% skeptical articles) and the conservative Wall Street Journal (28\% skeptical articles). However, differences did emerge on the editorial pages 
(Painter \& Ashe, 2012) and an analysis of conservative columnists (Elsasser \& Dunlap, 2013) revealed that they were all skeptical towards the existence of climate change and climate science.

\section{Methods and measurement}

\section{Quantitative content analysis}

To answer our research question, we conducted a quantitative content analysis of US print media. The aim was to include the most important news outlets (newspapers and magazines) with nationwide circulations in terms of their role as opinion leaders in general and especially on the topic of climate change. Furthermore, we included all publications used in former studies to be able to replicate their results. To test our second hypothesis we differentiate the newspapers according to their political tendency in more conservative/right-leaning versus more liberal/leftleaning media. Gentzkow and Shapiro (2010) developed a slant index for US daily newspapers. They calculate their index by comparing the words frequently used by Republicans or Democrats in political discussion with the extent to which the newspaper coverage resembles these words. Following their index we can categorize the Wall Street Journal as conservative and the New York Times, L.A. Times and Washington Post as liberal (see also Ho \& Quinn, 2008; Painter \& Ashe, 2012). The ideological leaning of USA Today and the Chicago Tribune is less clear. According to the categorizations they can neither be categorized as liberal nor as conservative, but as centrist. Additionally we analyzed the magazines Time Magazine, Newsweek (included until its final publication in December 2012) and National Geographic International. Following the classification developed by Groseclose and Milyo (2005) - they measure ideological content by counting think-tank citations - we can classify Newsweek and Time Magazine as liberal. As there is no classification for National Geographic International we exclude the respective articles $(n=2)$ for the test of our second hypothesis. Based on these considerations we classify the print media in our sample as follows:

- Conservative/right-leaning: Wall Street Journal

- Centrist: USA Today, Chicago Tribune

- Liberal/left-leaning: New York Times, L.A. Times, Washington Post, Newsweek, Time Magazine

Overall $10 \%$ of the articles in our sample were published in conservative, $15 \%$ in centrist and $76 \%$ in liberal media.

To identify the relevant articles we used the Factiva search engine with the key words "climate change" or "global warming"1 (for a similar approach see, Fisher, Waggle, Leifeld, 2013; Boykoff \& Boykoff, 2004; Painter \& Gavin, 2015). The key words had to appear anywhere in the full text. For the news magazine National Geographic International, the articles were searched manually following the same procedure.

Our sample period includes one year of coverage from June 1, 2012 to May 31, 2013. Out of all the articles containing the keywords $(N=2608)$ we drew a random monthly sample of 35 articles for further analysis, which results in 420 articles analyzed. An article became part of our sample if

\footnotetext{
${ }^{1}$ A pretest of different keyword combinations revealed that searching for "climate change" OR "global warming" identified all relevant articles discussing our topic.
} 
one of the key words was mentioned somewhere in the article and if the article included at least one actor-argument sequence, i.e. an actor putting forward at least a problem definition on the issue and additionally a cause, a consequence or a treatment recommendation (see below).

To locate our sample within the large issue cycle of climate change figure 1 displays the total amount of articles containing the keywords "climate change" or "global warming" for all the newspapers and magazines in our sample from 2000 onwards. The figure shows that our sample was drawn in a period with medium amount of coverage which leads us to conclude that we study today's courant normal of the debate about climate change in the US print media ${ }^{2}$.

Figure 1: Number of articles per year dealing with "climate change" or "global warming"

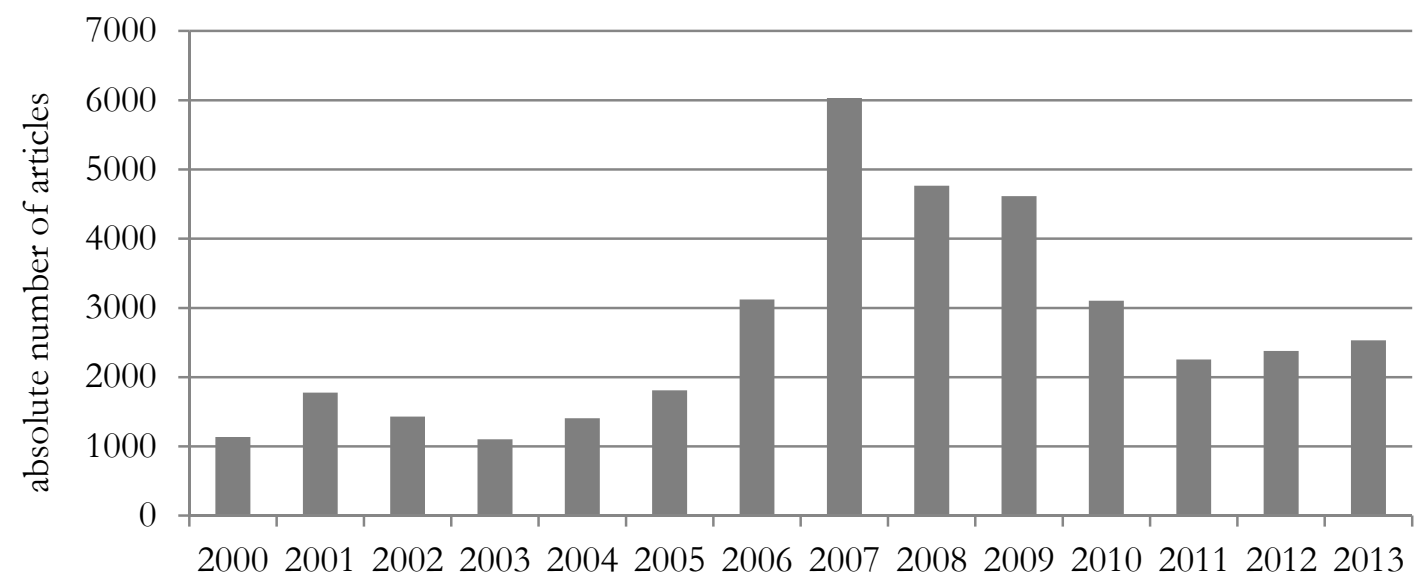

The coding took place on two levels: First, there were several variables on the document level (i.e. date, name of the newspaper, type of the article). Then the coders had to identify up to three most important actors (MIAs) in the article. Importance of actors was defined through the space that was devoted to their statements in the article. For the identified MIAs, the following variables were coded: position on climate change in general (does the MIA think that climate change is occurring and if yes, is climate change seen as a problem?), causes (human versus natural), positive/negative consequences and proposed treatment recommendations (are treatments proposed and if yes, should they be voluntary or binding? $)^{3}$. On average the articles contained two (1.94) most important actors. ${ }^{4}$ Six trained coders completed the coding. Krippendorff's Alpha for the variables on the article level was .84 and on the actor level .74 (see Appendix B).

\section{Identification of skepticism}

To identify skeptical voices in the articles and to distinguish between fundamental skepticism (trend and attribution skepticism) and impact skepticism, we relied on the measurement used in former

\footnotetext{
${ }^{2}$ For a more detailed measure of the number of articles dealing with climate change or global warming on a monthly basis see Gifford et al. (2015).

${ }^{3}$ The detailed codebook is available under: url; anonymized

${ }^{4}$ We have conducted a robustness check on our data asking whether our coding of a maximum of three actors voicing their opinions per article biases our results (e.g. makes us miss sceptical voices). A re-analysis of our data shows that it is only $12 \%$ of all articles $(n=50)$ in our sample where we missed out additional actors. We drew a random sample of those articles and coded also the additional actors in these documents. The recoding confirms our results. No changes occurred for Table 1, 2 and 4 and very minor changes occurred for Table 3 . However, these changes run counter to missing out sceptical voices.
} 
studies (Boykoff \& Boykoff 2004; Boykoff, 2007a; Painter \& Ashe, 2012) and adapted them to our study. As the level of analysis of former studies is the article, we aggregated our data so that the composition of MIAs within an article accounts for its classification.

Fundamental climate change skepticism. Within fundamental climate change skepticism we differentiate between trend and attribution skeptics. To measure trend skeptics we distinguish the following article types:

1. Only presents the argument that global warming exists

2. Presents both sides, but emphasizes that global warming exists

3. Presents a balanced account of debates surrounding the existence of global warming

4. Presents both sides, but emphasizes that global warming does not exist

5. Only presents the argument that global warming does not exist

To measure attribution skeptics - defined as denial of the anthropogenic contribution to global warming - we adapted the measurement used by Boykoff and Boykoff (2004). They analyze the discussion of anthropogenic global warming in each article and distinguish between the following article types:

1. Only presents the argument that anthropogenic global warming exists, clearly distinct from natural variations

2. Presents both sides, but emphasizes that anthropogenic global warming exists, distinct from natural variations

3. Presents a balanced account of debates surrounding the existence of anthropogenic global warming

4. Presents both sides, but emphasizes the dubious nature of the claim that anthropogenic global warming exists

5. Only presents natural causes for climate change [added for the present study]

Both types were coded on the level of the actors who expressed them in an article. To replicate the measurement used by Boykoff and Boykoff (2004), we aggregated our data to the article level. This means that an article classified as type 1 (see above) only contains actors (MIAs) who mention that global warming exists (trend skeptics) or who mention anthropogenic causes or dismiss natural causes (attribution skeptics). In articles of type 2 the majority of the MIAs approves the trend (trend skeptics) or describes anthropogenic causes (attribution skeptics). An article is balanced (type 3) if the same number of MIAs mention that global warming exists and deny the trend (trend skeptics) or the same number of MIAs mention anthropogenic and natural causes or one MIA mentions both equally (attribution skeptics). Article types $2-5$ give room for fundamental skepticism in varying degrees, whereas articles of type 5 represent the "purest" form of skepticism, as they only mention the argument that global warming does not exist or natural causes of climate change. To test our hypotheses and to make our results comparable to Painter \& Ashe (2012) we merge (separately for each type of skepticism) article types 2-5 into one measurement of articles containing skeptical voices. 
Impact skepticism. Impact skepticism has two dimensions: It includes the argument that action is not necessary or should at least not be mandatory and that the consequences of climate change are positive (Painter \& Ashe, 2012). We coded for each actor (MIA), which actions he/she supported to mitigate or adapt to climate change and for each mentioned treatment recommendation, we measured how the actor wants to implement it (as obligatory policy or as voluntary agreement or via funding). Additionally we coded for each MIA if he/she mentions positive or negative consequences regarding climate change.

First, to measure impact skepticism in line with Painter and Ashe (2012) we identified all articles in which at least one MIA mentions cautious or voluntary approaches to deal with global warming or states that no action is required or mentions positive consequences. Second, to replicate the results of Boykoff and Boykoff (2004) we additionally focused on one aspect of impact skepticism separately, the discussion of actions. In line with these authors we distinguish articles in which a majority of MIAs calls for action / obligatory policy rule from articles in which a majority of MIAs opine that no action is required or that voluntary agreements are sufficient. Finally those articles which are balanced in the sense that the same number of MIAs favor the one or the other position or that one MIA mentions both possibilities equally form the last category. 


\section{Results}

Our first hypothesis expects impact skepticism to be more salient in US print media coverage today than fundamental forms of skepticism. In our sample, 130 articles out of the 420 coded $(31 \%)$ contain some form of skeptical argument. Thus compared to the results of Painter \& Ashe (2012) the amount of articles containing skeptical voices has remained more or less constant - they found 34 per cent in 2009/2010

Concerning the different forms of skepticism (hypothesis 1), we see in table 1 that the overwhelming majority of skeptical articles contain impact skepticism. Fundamental skepticism (trend and attribution skepticism) does not play a relevant role in US print coverage which allows us to confirm hypothesis 1. Compared to the results of former studies (Boykoff \& Boykoff, 2004; Painter \& Ashe, 2012), impact skepticism has become much more important whereas fundamental skepticism has decreased over time. Further analyses reveal that all articles containing impact skepticism claim that global warming is happening and climate change is portrayed as problematic. These findings are in line with the definition of impact skepticism: the scientific consensus is acknowledged but the main goal has been maintained, that is to avoid binding policy regulations. Additionally there are only five articles where different types of skepticism are found within one article.

Table 1: Type of skepticism in US print media

\begin{tabular}{lll}
\hline & & 0 \\
\hline $\begin{array}{c}\text { FUND. } \\
\text { SKEPTICISM }\end{array}$ & Trend skepticism* & 8 \\
\cline { 2 - 3 } & Attribution skepticism* & 18 \\
\hline $\begin{array}{l}\text { N=130 articles containing skeptical voices towards climate change, } \chi^{2}=112.31, \mathrm{p}<.001 \\
* 3 \text { articles containing trend skepticism also contain attribution skepticism; } 2 \text { articles containing attribution skepticism } \\
\text { also contain impact skepticism }\end{array}$
\end{tabular}

Our first research question asks if print media in the US are still characterized by "balance as bias" primarily with regard to impact skepticism. To understand the role of the balance norm for reporting about climate change, we analyze its relevance for the discussed causes as well as for the actions (Boykoff and Boykoff 2004; Boykoff, 2007a). Starting with the discussed causes table 2 clearly shows the irrelevance of the balance norm here. Out of 420 articles, $45 \%$ ( $N=189)$ discuss the causes of climate change. Out of this sub-sample, $88 \%$ of the articles follow the scientific consensus, only discussing the anthropogenic contributions to global warming. Only $2 \%$ follow the "pure" skeptical view and claim natural causes as the main or exclusive reason for climate change. The proportion of balanced articles - which discuss anthropogenic and natural causes equally - is very low (5\%). This supports the results of Boykoff's (2007a) more recent study, which argues that $3 \%$ of articles in 2006 were balanced. 
Table 2: Discussion of the causes of climate change (attribution skepticism) ${ }^{5}$

\begin{tabular}{ll}
\hline Article type & $\%$ \\
\hline exclusive coverage of anthropogenic warming & 88 \\
\hline coverage of anthropogenic contribution dominant & 5 \\
\hline balanced accounts of anthropogenic contributions to warming & 5 \\
\hline skepticism of anthropogenic contribution dominant & 1 \\
\hline exclusive coverage of skeptical arguments & 2 \\
\hline $\mathrm{N}=189$ articles containing causes of climate change; $\chi^{2}=545.05, \mathrm{p}<.001$ &
\end{tabular}

We also study the role of the balance norm regarding the discussed actions (Boykoff and Boykoff, 2004). Table 3 shows that actions regarding climate change are discussed in $38 \%(n=160)$ of all articles dealing with climate change $(n=420)$. Focusing on those articles which refer to actions to address climate change, we find a slightly more balanced coverage compared to the causes. But, analogous to the results above, only a small number of articles is balanced ( $8 \%$ ). Consequently, we can say that the US print media coverage about climate change is not driven by the journalistic norm of balance (anymore). "Balance as bias" has diminished over time and only plays a minor role in the current coverage of climate change. It is thus not the balance norm that explains how sceptical voices enter the mass media debate.

Compared to the results of Boykoff and Boykoff (2004) the proportion of articles dominantly supporting immediate/mandatory actions as well as the number of articles centrally mentioning cautious/voluntary action has risen in our study (both had 11\% in the study of Boykoff and Boykoff, 2004). Thus, combined with the result that the share of balanced articles has diminished, it seems that the articles have become more clear-cut in their statement about either mandatory or voluntary/no actions to combat climate change.

Table 3: Discussion of the actions to combat climate change ${ }^{6}$

\begin{tabular}{ll}
\hline Article type & $\%$ \\
\hline immediate/mandatory action dominant & 46 \\
\hline balanced accounts regarding action & 8 \\
\hline cautious/voluntary action dominant & 46 \\
\hline $\mathrm{N}=171$ articles containing actions of climate change: $\chi^{2}=128.85, \mathrm{p}<001$
\end{tabular}

$\mathrm{N}=171$ articles containing actions of climate change; $\chi^{2}=128.85, \mathrm{p}<.001$

The second approach explaining the entrance of skeptical voices in US print media is political parallelism. In our third hypothesis, we expected conservative media to publish more articles containing skeptical voices than liberal media. As we see in table 4, our results contradict what we expected. We do not find any difference between conservative and liberal media in the amount of articles containing skepticism of global warming. As the results show, it is not political parallelism that creates a space for climate change skepticism in the US.

\footnotetext{
${ }^{5}$ Our sample includes a broader sample (more different news outlets and news as well as op-eds) than Boykoff \& Boykoff (2004) and Boykoff (2007). However the proportion of articles remains constant even if we filter our sample according to Boykoff \& Boykoff (2004) and Boykoff (2007).
} 
Table 4: Ideological leaning of the print media and climate change skepticism $(\%)^{6}$

\begin{tabular}{clccc}
\hline & & conservative & centrist & liberal \\
\hline FUnD. & Trend skepticism* & 2 & 2 & 3 \\
\cline { 2 - 5 } SKEPTICISM & Attribution skepticism* & 10 & 5 & 5 \\
\hline & Impact skepticism* & 27 & 21 & 24 \\
\hline No skepticism & 63 & 74 & 69 \\
\hline
\end{tabular}

$\mathrm{N}=418$ articles dealing with climate change (without National Geographic International), 41 in conservative, 61 in centrist and 316 in liberal media; $\chi^{2}=4.84$, n.s.

*3 articles containing trend skepticism also contain attribution skepticism; 2 articles containing attribution skepticism also contain impact skepticism

\section{Discussion}

The first goal of our study was to analyze to what degree and in what form climate change skepticism remains a characteristic of US print media coverage. Our results show that the amount of articles containing skepticism has remained more or less constant compared to former studies (e.g. Painter \& Ashe, 2012). Painter and Ashe (2012) explain the relatively high portion of climate change skeptics in the US print media coverage by arguing that the "Climategate" affair in 2009 paved the way for critical voices. They ask in their conclusion "if the presence of skeptical voices in the UK and US media has been maintained after the decline in media interest in Climategate" (Painter \& Ashe, 2012, p. 7). Based on our results, the question deserves an affirmative answer although there was no special "skepticism-friendly-event" in the period under study.

However, the discourse has matured - the manner in which the skepticism is expressed in US print media has changed over time. Whereas denial concerning the existence of global warming and its anthropogenic causes dominated former coverage (see for example Boykoff \& Boykoff, 2004; Painter \& Ashe, 2012), today the discussion focuses on the necessary (or unnecessary) actions to combat climate change. In concrete our results show a shift from these forms of fundamental skepticism to impact skepticism. This means that current climate change skeptics frame the discussion in a certain way claiming that binding regulations would harm the economy and threaten individual freedoms. How can this shift be explained?

In recent years, the scientific evidence for the existence of global warming and its anthropogenic sources has strengthened. Moreover, the Democrat's taking over of the White House in 2008 led to the decision of the Obama administration to put climate change - at least rhetorically - back on the political agenda. And the advent of the Tea Party movement onto the political scene in 2009 and the ensuing infighting in the Republican camp meant that fundamental climate change skepticism has become more and more a marker of those on the fringes of the Right. Transforming under these changing conditions, skepticism has become more nuanced. Framed as an "economy vs. ecology" issue and tying into a well-established anti-environmentalist discourse (Dunlap \& McCright, 2011), this more subtle form of skepticism has broadened its appeal from an ideological core to corporations, parts of the political elite and wider parts of the electorate by highlighting the economic repercussions of binding regulations.

\footnotetext{
${ }^{6}$ The results show the same pattern for different type of articles and are also true for op-eds/commentaries.
} 
The second goal of our study was to explain how and why skeptical arguments enter print media coverage. We therefore tested two different theoretical approaches, the journalistic norm of neutrality and the political parallelism hypotheses. Our results show that, similar to the more recent results of Boykoff (2007a), "balance as bias" does no longer explain the media's coverage of climate change. Equally, we do not find any political parallelism in newspapers as climate change skepticism occurs to the same extent in liberal as well as in the analyzed conservative outlet. This also illustrates skeptics' success. Today they have found a form of argumentation that advances their goals and is at the same time so subtle that it is covered by all type of media. As the political debate advances, their views have gained currency and become legitimate beyond the core of climate change skeptics (cf. Gamson, 1988, for the changing boundaries of legitimacy in discourse).

From a normative standpoint, this makes this form of skepticism dangerous, as it is not necessarily identifiable as such at first glance. Given that part of the scientific consensus on climate change is that immediate action has to be taken to mitigate global warming and its impacts, media coverage is not accurate concerning this point and a new form of informational bias seems to have emerged. As the form of coverage affects public opinion (Zaller, 1992) as well as political action (Baumgartner \& Jones, 1993), print media coverage dismissing the need to mitigate global warming may lead to the overall perception that no measures are needed. In the long term, this means that the coverage may contribute to the failure to ratify international agreements and hinder the implementation of a national climate change policy in the US.

A limitation of our study is, of course, that we only analyzed print media coverage. That we do not find fundamental skepticism there does not mean that it is not present in any form of media any more. For example, online communication, with its low entry barriers, offers many possibilities for skeptics to promote their arguments and climate skeptical bloggers as well as think tanks, etc. might thus be able to bypass traditional media to reach their audience. Moreover, with the emergence of what Chadwick (2013) has termed a "hybrid media system" that connects online and offline form of communication in complex ways, their voices might spill over from blogs and Websites to traditional media, above all conservative TV channels like FoxNews. Linked to that future research needs to show whether political parallelism is occurring in other media outlets - for example in TV. Another limitation of our study concerns reliability of coding. With Krippendorff values between .69 and .76 we are below the ideal value of .80 or above but are for all but one variable in line with current research practice (Lombard, Snyder-Duch, Bracken, 2002). The variable with the lowest Krippendorff ranking measures trend skepticism. It is this variable where we run the risk of over- or underestimation. Yet, since the difference between the types of skepticism is very substantial, it is rather unlikely we draw the wrong conclusion by stating that impact skepticism strongly outnumbers trend skepticism. Furthermore, Holsti scores on the same variable reveal a $92 \%$ coding agreement, showing that Krippendorff values correcting for agreements by chance should not be overestimated for variables that have only few levels (in our case four). Beyond, we included in our study only one conservative newspaper and compare it to several liberal ones. To strengthen the power of evidence further studies should widen the sample and include a broader set of conservative titles.

Finally, if it is neither the journalistic norm of balance nor political parallelism between print media and politics which paves the way for climate change skeptics to enter the mass media, future research will need to continue investigating the paths through which these voices enter public 
forums. Indexing (Bennett, 1990) might be a fruitful starting point as it includes the effects of the discourse of political actors on mass media coverage. From this perspective, climate change coverage reflects the range of voices among the political elite. Consequently, for the US, the political divide between Democrats and Republicans regarding climate change and the changing majorities in Congress might be key for understanding the strength and form of climate change skepticism in the mass media. 


\section{Appendix A}

Table 1: Different types of trend skepticism (\%)

\begin{tabular}{ll}
\hline Article type & $\%$ \\
\hline exclusive coverage that global warming exists & 97 \\
\hline dominant coverage that global warming exists & 1 \\
\hline balanced account of debates surrounding the existence of global warming & 1 \\
\hline dominant coverage that global warming does not exist & - \\
\hline exclusive coverage that global warming does not exist & 1 \\
\hline $\mathrm{N}=416$ articles mentioning the existing of global warming &
\end{tabular}

Appendix B: Detailed reliability scores for the used variables

1. Agreement concerning the identification of the three most important actors (MIAs): $77 \%$

2. Variables on the document level:

\begin{tabular}{lc}
\hline Type of the article & Krippendorff's Alpha \\
\hline$N=30$ documents; each coder was compared separately to a master coding
\end{tabular}

3. Variables on the actor-argument level:

\begin{tabular}{lc}
\hline & Krippendorff's Alpha \\
\hline Occurrence of climate change* & .69 \\
\hline Climate change seen as a problem* & .75 \\
\hline Causes of climate change & .75 \\
\hline Consequences of climate change & .76 \\
\hline Treatments & .76 \\
\hline$N=30$ commonly identified MIAs; each coder was compared separately to a master coding \\
*Holsti: $92 \%$ for "occurrence of climate change and 94\% for "climate change seen as problem" \\
(both variables have only four levels)
\end{tabular}




\section{References}

Aldy, J. E., \& Pizer, W. A. (2009). Issues in designing US climate change policy. The Energy Journal, 179-209.

Anderegg, W., Pra, J. W., Harold, J. \& Schneider, S. (2010). Expert credibility in climate change. PNAS, 107, 12107-12109.

Antilla, L. (2005). Climate of scepticism: US newspaper coverage of the science of climate change. Global Environmental Change, 15(4), 338-352.

Baumgartner, F.R. \& Jones, B.D. (1993). Agendas and instability in American politics. Chicago: University of Chicago Press.

Bennett, W.L. (1990). Toward a theory of press state relations in the United States. Journal of Communication, 40(2), 103-127.

Boykoff, J. (2012). US media coverage of the Cancun climate change conference. PS: Political Science \& Politics, 45(2), 251-258.

Boykoff, M.T. (2007a). Flogging a dead norm? Newspaper coverage of anthropogenic climate change in the United States and United Kingdom from 2003 to 2006. Area, 39(4), 470481.

Boykoff, M.T. (2007b). From convergence to contention: United States mass media representations of anthropogenic climate change science. Transactions of the Institute of British Geographers, 32(4), 477-489.

Boykoff, M.T. \& Boykoff, J.M. (2004). Balance as bias: global warming and the US prestige press. Global Environmental Change, 14(2), 125-136.

Boykoff, M.T. \& Boykoff, J.M. (2007). Climate change and journalistic norms: A case-study of US mass-media coverage. Geoforum, 38(6), 1190-1204.

Boykoff, M.T. \& Mansfield, M. (2008). 'Ye Olde Hot Aire': reporting on human contributions to climate change in the UK tabloid press. Environmental Research Letters, 3(2), 024002.

Boykoff, M. T. \& Rajan, S. R. (2007). Signals and noise. EMBO reports, 8(3), 207-211.

Brownstein, R. (2010). GOP Gives Climate Science a Cold Shoulder. National Journal. Available online: http://www.nationaljournal.com/columns/political-connections/gop-givesclimate-science-a-cold-shoulder-20101009 (accessed 3 May 2015).

Brulle, R. (forthcoming). The development, structure, and influence of the U.S. national climate change movement. In Y. Wolinsky-Nahmias (Ed.), Climate change policy and civil society. Thousand Oaks: Congressional Quarterly Press.

Captsick, S. B. \& Pidgeon, N. F. (2014). What is climate change scepticism? Examination of the concept using a mixed methods study of the UK public. Global Environmental Change, 24, 369-401. 
Carvalho, A. (2007). Ideological cultures and media discourses on scientific knowledge: re-reading news on climate change. Public Understanding of Science, 16(2), 223-243."

Carvalho, A. \& Burgess, J. (2005). Cultural circuits of climate change in UK broadsheet newspapers, 1985-2003. Risk Analysis, 25(6), 1457-1469.

Chadwick, A. (2013). The bybrid media system. Politics and power. Oxford: Oxford University Press.

Diethelm, P. \& MacKee, M. (2009). Denialism: What is it and how should scientists respond? European Journal of Public Health, 19, 2-4.

Dispensa, J.M. \& Brulle, R.J. (2003). Media's social construction of environmental issues: focus on global warming-a comparative study. International Journal of Sociology and Social Policy, 23(10), 74-105.

Doran, P. T. \& Zimmerman, M. K. (2009). Examining the scientific consensus on climate change, EOS, 90(3), 22-23. Available online: http://tigger.uic.edu/ pdoran/012009_Doran_final.pdf (accessed 2 Oct. 2014).

Dryzek, J. S., Downes, D., Hunold, C., Schlosberg, D. \& Hernes, H. K. (2003). Green States and Social Movements: Environmentalism in the United States, United Kingdom, Germany, and Norway: Environmentalism in the United States, United Kingdom, Germany, and Norway. Oxford University Press.

Dunlap, R. E. \& McCright, A. M. (2008). A widening gap: Republican and Democratic views on climate change. Environment: Science and Policy for Sustainable Development, 50(5), 26-35.

Dunlap, R. E. \& McCright, A. M. (2010). Climate change denial: sources, actors and strategies. In C. Lever-Tracey (Ed.), Routledge Handbook of Climate Change and Society (pp. 240-259). New York: Routledge.

Dunlap, R. E. \& McCright, A. M. (2011). Organized climate change denial. In J. S. Dryzek, R. B. Norgaard, \& D. Schlossberg (Eds.), The Oxford Handbook of Climate Change and Society (pp. 144-160). Oxford: Oxford University Press.

Dunwoody, S. \& Peters, H.P. (1992). Mass media coverage of technological and environmental risks: A survey of research in the United States and Germany. Public Understanding of Science, 1(2), 199-230.

Elsasser, S.W. \& Dunlap, R.E. (2013). Leading voices in the denier choir: Conservative columnists' dismissal of global warming and denigration of climate science. American Behavioral Scientist, 57(6), 754-776.

Entman, R. (1989). Democracy without citizens: Media and the decay of American Politics. New York: Oxford University Press. 
Feldman, L., Maibach, E. W., Roser-Renouf, C. \& Leiserowitz, A. (2011). Climate on cable: The nature and impact of global warming coverage on Fox News, CNN, and MSNBC. The International Journal of Press/Politics, 17, 1-29.

Fisher, D. R., Leifeld, P. \& Iwaki, Y. (2013). Mapping the ideological networks of American climate politics. Climatic Change, (116), 523-545.

Fisher, D., Waggle J. \& Leifeld P. (2013). Where does political polarization come from? Locating polarization within the U.S. climate change debate. American Behavioral Scientist, 57(1), 7092.

Gallup (2014a). Climate Change Not a Top Worry in U.S.. Available online: http://www.gallup.com/poll/167843/climate-change-not-top-worry.aspx?version=print (accessed 2 Oct. 2014).

Gallup (2014b). A Steady 57\% in U.S. Blame Humans for Global Warming. Available online: http://www.gallup.com/poll/167972/steady-blame-humans-global-warming.aspx (accessed 2 Oct. 2014).

Gamson, W. A. (1988). Political discourse and collective action. International Social Movement Research, 1, 219-44.

Gentzkow, M. \& Shapiro, J. M. (2010). What drives media slant? Evidence from U.S. daily newspapers. Econometrica, 78(1), 35-71.

Gifford, L., Luedecke, G., McAllister, L., Nacu-Schmidt, A., Wang, X., Andrews, K., Boykoff, M., and Daly, M. (2015). World newspaper coverage of climate change or global warming, 2004-2015. Center for Science and Technology Policy Research, Cooperative Institute for Research in Environmental Sciences, University of Colorado. Available online: http://sciencepolicy.colorado.edu/media_coverage [24.04.2015].

Groseclose, T. \& Milyo, J. (2005). A measure of media bias. The Quarterly Journal of Economics, 120(4), 1191-1237.

Grundmann, R. (2007). Climate change and knowledge politics. Environmental Politics, 16(3), 414432.

Grundmann, R. \& Scott, M. (2014). Disputed climate science in the media: Do countries matter? Public Understanding of Science, 23(2), 220-235.

Gupta, J. (2010). A history of international climate change policy. WIREs Climate Change, 1, 636653.

Hallin, D.C. \& Mancini, P. (2004). Comparing media systems: Three models of media and politics. Cambridge: Cambridge University Press. 
Hickman, L. (28.08.2013). The era of climate change 'denial' is over. The Guardian. Online available: http://www.theguardian.com/environment/blog/2013/aug/28/era-climatechange-denial-over [16.04.2015].

Hiles, S. S. \& Hinnant, A. (2014). Climate change in the newsroom: Journalists' evolving standards of objectivity when covering global warming. Science Communication, 36(4), 428453.

Ho, D. E. \& Quinn, K. M. (2008). Measuring explicit political positions of the media. Quarterly Journal of Political Science, 3, 353-377.

Hobson, K. \& Niemeyer, S. (2012). "What sceptics believe": The effects of information and deliberation on climate change scepticism. Public Understanding of Science, 22(4), 396-412.

Hoffman, A. J. (2011). Talking past each other? Cultural framing of skeptical and convinced logics in the climate change debate. Organization \& Environment, 24, 3-33.

IPCC (Eds.). (2014). Fifth assessment report. Available online: www.ipcc.ch (accessed 2 Oct. 2014)

Iyengar, S. \& Hahn, K.S. (2009). Red media, blue media: Evidence of ideological selectivity in media use. Journal of Communication, 59(1), 19-39.

Jacques, P. J., Dunlap, R. E., \& Freeman, M. (2008). The organisation of denial: Conservative think tanks and environmental scepticism. Environmental Politics, 17(3), 349-385.

Leiserowitz, A. A., Maibach, E. W., Roser-Renouf, C., Smith, N., \& Dawson, E. (2013). Climategate, public opinion, and the loss of trust. American Behavioral Scientist, 57(6), 818837.

Levendusky, M.S. (2013). Why do partisan media polarize viewers? American Journal of Political Science, 57(3), 611-623.

Lombard, M., Snyder-Duch, J. \& Bracken, C C. (2002). Content analysis in mass communication. Assessment and reporting of intercoder Reliability. Human Communication Research, 28(4), 587-604.

Lutsey, N., \& Sperling, D. (2008). America's bottom-up climate change mitigation policy. Energy Policy, 36(2), 673-685.

McCright, A.M. \& Dunlap, R.E. (2003). Defeating Kyoto: The conservative movement's impact on US climate change policy. Social Problems, 50(3), 348-373.

McCright, A.M. \& Dunlap, R.E. (2011). The politicization of climate change and polarization in the American public's views of global warming, 2001-2010. The Sociological Quarterly, 52(2), 155-194.

Nisbet, M.C. (2009). Communicating climate change: Why frames matter for public engagement. Environment: Science and Policy for Sustainable Development, 51(2), 12-23. 
Nisbet, M.C. (2011). Public opinion and participation. In J. S. Dryzek, R. B. Norgaard, \& D. Schlossberg (Eds.), The Oxford Handbook of Climate Change and Society (pp. 355-368). Oxford: Oxford University Press.

Nisbet, M. \& C. Mooney (2007). Science and Society: Framing Science. Science, 316, 56.

Oreskes, N. (2004). Beyond the ivory tower: the scientific consensus on climate change. Science, 306(5702), 1686.

Painter, J. (2011). Poles apart: The international reporting of climate skepticism. Oxford: Reuters Institute for the Study of Journalism.

Painter, J. \& Ashe, T. (2012). Cross-national comparison of the presence of climate scepticism in the print media in six countries, 2007-10. Environmental Research Letters, 7(4), 1-8.

Painter, J. \& Gavin, N. T. (2015). Climate Skepticism in British Newspapers, 2007-2011. Environmental Communication, 1-21.

Rahmstorf, S. (2004). The climate skeptics: In weather catastrophes and climate change: Is there still hope for us? Available online: http://www.pik-potsdam.de/ stefan/Publications/ (accessed 2 Oct. 2014).

Russill, C. \& Nyssa, Z. (2009). The tipping point trend in climate change communication. Global Environmental Change, 19(3), 336-344.

Scruggs, L. \& Benegal, S. (2012). Declining public concern about climate change: Can we blame the great recession?. Global Environmental Change, 22(2), 505-515.

Selin, H. \& van Deveer, S. D. (2010). US climate change politics and policymaking. WIREs Climate Change, 2, 121-127.

Stocking, S. H. (1999). How journalists deal with scientific uncertainty. In S. M. Friedman, S. Dunwoody \& C. L. Rogers (Eds.), Communicating uncertainty: Media coverage of new and controversial science (pp. 23-41). Mahwah, New Jersey: Lawrence Erlbaum.

Stocking, S.H. \& Holstein, L.W. (2009). Manufacturing doubt: Journalists' roles and the construction of ignorance in a scientific controversy. Public Understanding of Science, 18, 23 42.

Washington, H. \& Cook, J. (2011). Climate change denial. Heads in the sand. London, Washington: Earthscan.

Xie, L. (2015). The story of two big chimneys: A frame analysis of climate change in US and Chinese newspapers. Journal of Intercultural Communication Research, 44(2), 151-177.

Zaller, J. (1992). The nature and origins of mass opinion. Cambridge University Press. 